\title{
The Effectiveness of Comic Strip As Media to Improve the Students' Reading Comprehension on Narrative Text of MTs Ar-Rahman Langkat
}

\section{Rudang Mayang Sari Manik}

University of Sumatera Utara (USU), Medan, Indonesia

\section{Abstract}

In this research, the writer would deal with reading skill based on the consideration that success in reading will be very important for students both for academic and vocational advancement. For mor than a quarter of a century language teachers have been dominated by the idea that speech is the primary from of languange, writing is secondary. So, it is logic that there is such a common sense that teaching languange is nothing more than a remedial stage of preparation to the more rigorous. Moreover,

Corresponding Author: Rudang Mayang Sari Manik rudangluvallah@gmail.com

Received: 1 July 2019

Accepted: 18 July 2019

Published: 31 July 2019

Publishing services provided by Knowledge E

(c) Rudang Mayang Sari

Manik. This article is distributed under the terms of the Creative Commons Attribution License, which permits unrestricted use and redistribution provided that the original author and source are credited.

Selection and Peer-review unde the responsibility of the AICLL 2019 Conference Committee. reding is regarded as somewhat dull because today's generationg ets philosopy from thr movie. In fact, studying literature can assure intellectual stimulation even at the beginning stages of learning.

According to the statement above, there is a challenge on the foreign language teacher to provide exposure to language and to provide opportunities for learning through classroom activities. In class, teacher have significant rule to bring out the fun class to the students. So, teacher should try to get students read and develop their skills that are aimed to improve their ability and will to read. Theey should be a good facilitator in creating nd building an effecctive reading class. One way to conduct the clss to be more interesting is by using a fresh and interesting material to be brought to clas. This case is also happend in MTs Ar-Rahman Langkat that only some of material in the book about reading comprehension and many students can not understand what the next talk about.

In other words, comic is unification, work of art among fine literary works in which there are usual froms are the verbal explanation in fixedd sequence and has cartoon story as theme. Reading cimics is more than the material in hand, that it involves a certain immersion into the cultural of the comics that one readers to get the right visualization. Teacher should be sekective in choosing teaching media/ aids. In the writer's opinion, teaching English on reading skill using comic strips was one of teacjing aid which student's were given chance to learn English more fun.

1. Introduction

Keywords: effectiveness, comic, reading comprehension.

\subsection{Background of study}

Reading is a kind of activity in recieving messages thought wirtten text. In getting the information from a wirtten source, people must have good reading comprehension ability, in order to comprehend the information. Reading is a process where by one looks at 
and understand what has ben written. The keyword here is comprehend or udnerstand, merely reading aloud without understanding does not count as reading. (Salim razi, the effects of cultural schema and reading activities on reading comprehension: omsekiz Mart, Turkey, P.2) Reading is the process of constructing meaning from written text. It is a complex skill requiring the coordination of a number of interrelated sources of information. (Anderson et al.definition of reading, 19885. P. 14) Reading is the process of contructing meaning trough the dynamic interaction among: the rreader's existing knowledge., the information suggested by the text being read, and the context of the reading situation. (Wixson, Peters, Weber \& Roeber, 1987, citing the new definition of reading for Michigan. P.276) Reading is the process undertaken to reduce uncertainty about meanings a text conveys. The process results from a negotiation of meaning between the text and its reader, the knowledge, expectations, and strategies a reader uses to uncover textual meaning all play decisive roles way the reader negotiates with the text's meaning.

Reading does not draw on one kind of cognitive skill, nor does it have a straighforward outcome most texts are understood in different ways by different readers. Reading is a basic life skill. It is a cornerstone for a shild's success in school, and indeed throughout life. Without the ability to read well, opportunities for personal fulfillment and job success inevitably will be lost. Becoming a nation of readers: th ereport of teh commision on reading. Reading as the process of constructing meaning from written texts. Skills reading are:

- constructive: learning to reason about written material using knowledge from everyday life and from disciplined fields of study

- fluent: mastery of basic processess to the point where they are automatic so that attention is freed for the analysis of meaning.

- Strategic: controlling one's reading in relation t one's purpose, the nature of the material and whether one is comprehending

- Motivated: able to sustain attention and learning that written material can be interesting and informative and

- A lifelong pursuit: continuous practices, development and refinement (Richard Anderson and the commission on reading define)

Reading comprehension is a process of making sense of written ideas through menaingfull interpretation and interaction with the langguage abilities. (Grabe and stoller. 2002. Teaching and researching reading. England: pearson education, p.9) Here, the reader must have available abolity in the process of interpresting the text 
appropriately in comprehending the text. Reading comprehension is the ability to read the text is infulenced by their traits skills, one of which isthe baility to make inferences. If word recognition is difficult, students use too much of their processing capacity to read individual words, which interferes with their ability to comprehend what is read. There are a number of approachess to improve reading comprehension, including improving one's vocabulary and reading strategies. Reading comprehension is defined as the level of understanding of the text/message. (Keith rayner, barbara foorman, charles perfetti, david pesetsky, and mark seidenberg (november 2001) "how psychological science informs the teaching of reading")

Thats why the writer want to conclude this matter under the title:

"The Effectiveness Of Comic Strip As Media To Improve The Student's Reading Comprehension On Narrative Text At The Eight Grade Students Of Mts.S Ar Rahman, Langkat"

\section{Literature Review}

\subsection{Significance of study}

\subsubsection{Theoritical}

The writer expects this research had some significance. They were limited below:

1. This experimental research: could be used as process to improve the teaching performance both teacher and researcher

2. For students: it might motivate students to improve their interest in reading since they would find out that english reading material was not complicated, boringm and monotonous.

3. For teachers: it might show teacher that comic and other forms of interesting material could be used for teaching reading. This study also could give motivation to te english teacher to create new ways or media in teaching learning english

4. The other researcher: it can be used as a comparison and references to make the same research deeply or to make the new research in a new title on this title

\subsection{Theoritical concept}




\subsubsection{Improving reading comprehension}

Improve in become or make better. (Oxford dictionary (fourth edition), (Iondon: oxford university press:2009)) Reading as comprehension is defined as the level of understanding of a writing text. In this case, reading comprehension allows them to understand what text being written.

Allah says: "recite in the name of Allah who created, created man from a clinging substance. Recite and your Lord is the most generous, who taught by the pen-taught man that which he knew not" (Qs. Al-Alaq: 1-5)

History: we have explained in the introduction, when the angel said to the prophet (peace be upon him). Read, the latter replied i cannot read! This indicates that the angel had presented these words of the revelation before him in the written form and had asked him to read them. For if the angel had meant that he should repeat what he recited, he should not have replied, saying: i can not read!

Means: Allah was command to us should reas than you know anything. Wiseword said that library is windows of world and books are the way to around the world.

According to the verses above, it is clear that wuran emphasizes reading skill to build knolledge and understanding in order to mastery the world. As we enter to twenty firs century, distorting and changing of global demographic, technology, science and information are leading to unprecedented level of intercultural contact in both domestic and international areas. Meanwhile, reading is known as a tool for human being toaccess worlds of ideas and feelings. Thus, reading itself can be regarded as well as the knowledge of the ages and visions of the future. (Mahmud Y. Yazid, the quran english translation of the meaning of the quran (Lebanon. Dar Alchaura, 1980), p.457)

It is commonplace, perhaps inevitably to bring and match the global condition into the curriculum in formal education. In school there are four skills that the students have to master. They are speaking, listening, reading and writing.

This aim is reasonable since the punch line of the teaching foreign languagae is to be able to communicate in other language. Communicative using other language is not simple as talking in native language because it means shifting frames and norms. There is something we should not say or taboo. Shortly, studying other language involves not only words and structures, it is kind of thinking differently about language and communication. The end of process in studying other language is cross culture understanding. The big question is how can we begin to understand another way of thinking? The answer is by reading. 


\section{Research and Discussion}

\subsection{Research design}

This research was conducted by classroom action research (CAR). According to Wallace that classrom action research is different from conventional types of research. (Wallace M,J 1998. Action research for language teacher: united kingdom: cambrige university.)

Classroom action research consisting of three words that could be understood as follows understadning:

1. Class -is a group of students who are in the same recieving the same lesson from teacher. Not a form of classroom but a group of students who were studying by combining the understanding of three word limit could be concluded that the research was a class action againts activities that are deliberately raised and occurs in a classroom

2. Action -something movement activities that are deliberately made with a specific purpose, which is this study from a series of cycles of activity.

3. Reserach - examine the activities of an object, use the rules of a particular methodology to obtain data or information useful to improve the quality of a thing that interest and important for researcher.

Action research has three conditions that must be exist. Firstly, a project relates to a social practice, regarding as form of strategy action susceptible of improvement. (David Hopkins, Looc cit, p. 112-113)

Thus, action research aims at improving student's learning and the outcomes of teaching learning process. Moreover, it concerns to four steps namely: planning, action, observation and reflection.

The development of the idea of action research is generally attributed to Kurt Lewn, who in the immediate post-war periode used it as a methodology for intervening in and researching the major social problem of the day. Lewin maintained that through action research advances in theory and needed social changes might simultaneously be achieved. (David Hopkins, A teacher 's guide to classroom research, open university press, england. P 48)

It is focused on individual or small group professional practice and it is not concerned it general statement. Instructors use data readily available from their class in order to answer practical question about teaching and learning in the classroom. 
Put simply, action research is "learning by doing" it is conducted by the researcher as the teacher. She/he needs to know what is actually happening in the classroom, collecting the data and evaluating her/his effort are. And if it is not satesfying, try again until showing the increasing changing.

Based on the statements above it can be stated that classroom action research (CAR) aims to effectivness of comic strip and the outcomes of teaching learning process by changing in many aspects of learning, one of them is strategy in order to make a good quality of learning process, it also done in a class.

\subsection{The time and place of study}

This research will be held in the second grade student of Mts Ar Rahman Langkat

\begin{tabular}{l|l|l|l} 
No & Male & Female & Total \\
1 & 13 & 11 & 24
\end{tabular}

\subsection{Population and sample}

The population of this study was second grade student of MTs S Ar Rahman Langkat.

Author follows the research based on the following consideration:

- The writer has observed english teaching in MTs S Ar Rahman Langkat and it found that the students seemed do not understand what is being reading sentence, paragraph or story. And it is also proved by the test given by the teacher that some of them souldn't' answer some questions given by the teacher

- There are many students sleepy when the lesson time, so the writer want to apply this material that has never done before.

- The school is a place when the writer studied, so the witer wand to build up the increasing reading comprehension to all the students there.

\subsection{Operational definition}

To avoid misinterpretation of terms and in order to focus on the variable of this study, here will provide the terms used in this study that students' to effectiveness comic strip on reading comprehension.

The indicators in effectiveness comic strip as media on reading comprehension the result will be given to them they are: 
- The students can understand about the meaning of their narrative text, because use comic. They can got the meaning by look the comic.

- The effectiveness of comic strip as media to improve the students' reading comprehension

\subsection{Instrument of collecting data}

\subsubsection{Observation}

The objects of the writer observation are:

- Observation sheet: Observation sheet will be used to identify all the conditions that happen duringn teaching and leraning process. The researcher use observation to find out the scope of obervation, they are location, facilities, teaching learning process, the condition of students and condition of class at the location of research.

- Test: Test is sequence practice which is used measure skills, intelligence, abillity and aptitude own by individual or group. There are two kinds of this classroom action research (CAR). Test is used to measure language skill of the subject being researched. Instrument in form of test can be used to find out the basic competence and achievement. (Ibid, P.223) Test is a set of questions and exercises used to measure the achievement or capacity of the individual or group in order to discover how students are thinking and using the target language (english). Test is used to measure the person's competence and to achieve the objective. This methode was used to get subject's score in reading comprehension. The form of test which was used completion.

1. Pre test

Pre-test is the test before use the comic strip

\section{Post test}

Post-test function is to know th emeans of the score experimental group.

The procedures of this test done like:

Before the procedures of data collection begin, reading evaluation will be given to the students in the first meeting to know the basic knowledge of teh students in reading comprehension.

1. Than, the students will hear the explanation from the teacher how to do the media. 
2. Students will be given time to read the comic strip and answer the questions

3. Collect the test from the students when time is over

4. And the last, make evaluation and give score to the students answer.

Arranging instument of the test

1. Controlling material would be assessed was reading comprehension skill of narrative text.

\section{Set the type of test format}

The objective of this research is to find out the effectiveness of comic strips to improve students' reading comprehension skill of narrative text. Abundant examples of reading comprehension questions can be found inevery teacher's testing file, as wel as in literature and in standardized language test available commercially. Reading comprehension skill is not more understanding information in a text. However, comprehension abilities are much more complex than it. There are other processes required for reading comprehension such as connecting text to background knowledge, summarizing information, making inference, paying attention to text structure, guessing the meaning of a new word from content, and also reflecting on what has been learned from the text. Therefore, type of test used in this research is completion.

- Interview Interview will be used to know the feeling, problem and other condition of the students or teacher. It can answer activities which is done by researcher that asked with english teacher and students to collect instrument about the students when teaching learning process.

Teacher and students are the objects of interview in finding some information related to the research. The question include the situation in the class during learning process, include the students' ability in reading. The research does the interview to the teacher at the first time by phone and meet several times before the research held and the researcher interview the students in the classroom after the application of comic strip in the class.

- Document

- Acccording to Arikunto, documentation refers to the method where the researcher investigates written object such as books, magazine, etc. (Suharsimi arikunto, prosedur. P.158) 


\section{The Data}

This study applied qualitative and quantitative data. The quantitative data were taken from the mean of the students in making multiple choice tests.

The qualitative data were taken from observation sheet, documentation, diary notes, and interview. The data were taken only one class. This research were done in two cycles. There were two topics and each topic consisted of three meetings and two meetings. Every cylce consisted of four steps of classroom action research, namely: planning, acting, observing, and reflecting. The first cycle was done in three meetings, included of orientation test and the second one were done two meeting. So, totally there were five meetings in this research.

(a) The Quantitative Data

The qualitative data were taken from the result during conducted research in five meetings. The reading test was given to the students in forms of pre test, post test of cycle I and post test of cycle II, the first test as pre-test was given before conducting action in the first cycle. So, the test was given to the student without any treatment. The last of cycle I and cylce II were given to the stduents after teaching for each cycle had been completely finished.

(b) The Qualitative Data

In the qualitative data there were some instruments used: observation sheet, interview, diary note and documentation.

i. Observation Sheet

Observation sheet was used to identify all the conductions that happened during the teaching learning process. The observation was focuses on the situation of teaching learing process in which comic strip as media was applied, student's activities and behaviour, and interaction between teacher and students in the class. And it can be seen in appendix.

In the observation sheet, it noted that the students were interest and enthusiastic and enjoyable in learning reading comorehension by comic strip as media.

ii. Interview Sheet

Interview sheet was used to know the feelings, problems, and other conditions of the students or to collect information about students' attitudes, perception, and point of view in learning english especially comprehending the text. The research gave interview sheet twice: in the first interview was done before conducting this research, and the second interview was 
done in the last cycle. The researcher interviewed the teacher and students. In the first meeting, they were interviewed about their problems in reading comprehension. While the last interviewed, they were interviewed about their respond or comments about the effectiveness comic strip as media. The interviewed which was done in the last meeting with teacher and students gave good response or opinion about the effectiveness comic strip as media which can be improved the students' achievement in reading comprehension on narrative text. Based on the interview, it can be conclude the students had understood about the reading text. And they could understand the stories by using comic strip media. They said that media help them in comrprehending the text. The interview sheet with english teacher can be seen in appendix and interview sheet with the students can be senn in appendix.

iii. Diary Notes

The diary note was used to save the observation result of the writer herself during the research and it would be written dialy. The research used diary note to note all result of observations which contained all of te activity and progress during learning process including reflection and evaluation of comic strip as media in teaching reading comprehension. Here are some example of notes: it was found that the students were focused in comprehending the text in the begining of the research. And there were some students who did not know what the text about. They seemed lazy and confused to begin the reading. But after they listened the teachers' explanation aboyt the text and comic strip as media, they were serious in reading and they could understand the story easly. They did not confuse anymore about reading the text, becouse comic strip as media guided them in constructing the stories.

\section{Data Analysis}

The distribution of gaining score on reading test of pre-test

$\mathrm{P} 1=$ unsuccessful $=21$ students $=87,5 \%$

$P 2=$ successful $=3=12,5 \%$

It was conduct that the students's achievement in reading comprehension was still low.

The distribution of gaining score on reading test of post-test 1

$P 1=$ unsuccessful $=5$ students $=20,8 \%$ 
$\mathrm{P} 2=$ successful $=19$ students $=79,2 \%$

It could conclude that the students' achievement in reading comprehension was improved.

The distribution of gaining score on reading test of post-test II

$\mathrm{P} 1=$ unsuccessful $=0$ student $=0 \%$

P2 $=$ successful $=24$ students $=100 \%$

Post-test cycle II was ctegorized success. The result of standar of (SKM) criteria success minimum $>65$ score achieved. Student's achievement in reading comprehension on post-test II was classified success.

\section{The Second Cycle}

The first cycle was started at the first meeting until the third meeting. In the second meeting, the researcher was expected that the result from the students was better than the first cycle. The second cycle was done but the researcher in order to get the better improvement of the students. In the second cycle, the eresearcher felt better to begin because the researcher had already got the reflection from the first cycle to be used as the information on the students' problem. Similar to the first cycle, the researcher conducted to the second cycle with the same steps as follows:

Planning: In the cycle, comic strip as media was applied in teaching learning process. In this cycle, teaching learning process more emphasized students in reading comprehension to distinguish them. The researcher through comic strip as a media that in short stroy. Especially in descriptive text that can make the students more understand, interest, and enjoy in learning reading.

Action: The research was tried to the students and was motivated them to incrrease their achievement in reading comprehension by used comic strip as media.

Observation: The observation was done for the second cycle. The students' activity during teaching learning process had been observed.

(a) The students were not confused about the steps and ways of comic strip as media

(b) Many students were active in doing ask, even some of them were make noisy when teaching-learning process

(c) Many students tried to express their opinion confidently

(d) The researcher also saw they did not have any problem in doing their exercises. 
Reflection: In this phase, th efeedback of the teaching - learning process was taken from the result of the observation. As the observation and result test, the researcher could be concludes as follows:

(a) The researcher could be increase on the student's achievement in reading comprehension by using comic strip as media. It was based on the observation sheet that showed and improved every meeting. Every students had braveness to ask what they did now know and gave their opinion.

(b) Students' score had improvement too. It was based on the percentage of the students' score there were $79,2 \%$ at the post-test of cycle I and there were perfect $100 \%$ at the post-test of cycle II. The improvement of the students' score from the post-test of cycle I and cycle II was $20,8 \%$. It made the researcher felt that the cycle could be stopped because the students could be mastering in reading comprehension.

(c) Researcher finding and discussion

Applying comic strip ad media in teaching learning process improved the students' reading comprehension. It was proved by the data, that showed the progression mean of the students. The mean of the first cycle was $79,2 \%$ while the mean of second cycle was perffected. It was indicated that the scores and the men in second cycle were better than first cycle.

The percentage of students who got point $>65$ also grew up. In the pre-test, the students who got point $>65$ were only 3 students $(12,5 \%)$. In the post-test of cycle I students who got point $>65$ there were 19 students $(79,2 \%)$. The post-test of cycle II, students who got point $>65$ there were perfected (100\%). For the total imporvement of the students' score from pre-test to post-test of cycle II was $87,5 \%$. In other words the students' achievement reading comprehension was become well in the first meeting to the next meeting.

The researcher also used qualitative data, besides the quantitative data. The qualitative data were organized from the diary notes, interview, observation sheet and documentation indicated that the students got improvement in comprehending the text, and the students given their attitude and response during teaching learning process. Based on the result of the quantitative and qualitative data, it was indicated that the action and applying of comic strip as media had been improve the students' achievement in reading comprehension. 


\section{Conclusion and Suggestion}

\section{1. conclusion}

1. After analyzing the data, it was found out that the students' achievement in reading comprehension before applying the comic strip as media was low. It was showed from the mean of pre-test was $12,5 \%$. Where there was only 3 students who got successfull score sriteria above 65 or it was only $12,5 \%$ and 21 students who got unsuccessful or it was $87,5 \%$

2. In post-test cycle I and post-test cycle II, after the comic strip as media was applied. By using the comic strip as media the students are interested, actively, enthuasiastic and joyfully in teaching learning process. From the score of students' test, it was found the students' achievement in reading comprehension got improvement through comic strip as media. The result of the data analysis showed that here was an improving on the students' achievement in reading comprehension from each cycle. After doing post-test I, there was an improvement of the result of the students mean was $79,2 \%$. Where 19 students who got successful score criteria above 65 or it was only $79,2 \%$ and 5 students who got unsuccessful score criteria above 65 or it was $20,8 \%$. The doing an improvement in second cycle after reflection in the first cycle, there was an improvement of students' mean perfected. Where all the students who got successful score criteria above 65 or it was $100 \%$. In other words, the students' achievement inreading comprehension was improved. And based on interview sheet, observation sheet, diary notes, and documentation, it showed that the expression and excitement if the students were also improved.

3. Based on the result data analysis, showed that there was an improvement in the students' achievement in reading comprehension if taught comic strip as media. It was showed from the observation sheet, interview shett and diary notes. It was found that the teaching learning process run well. The students were active, enthuastic, interested, and enjoyable in following teaching learning process. In brief the research finding showed that coomic strip as media dignificantly improved tudents' achievement in reading comprehension. Based on the research finding, it could be concluded that teaching reading through comic strip as media could improve the students'achievement inr eading comprehension inMTs S Ar Rahman Langkat and it denotes that the research hypothesis is accepted. 


\subsection{Suggesstion}

Having seen the result of study, the following suggesstion are offered to be consider:

1. For the english teacher, should apply comic strip as media in teaching reading comprehension so that the students can be more interest, active, enthusiastic and enjoy during teaching learning process

2. For the student, it is suggested to use comic strip as media in learning english because this media can help the students to make them understand the text by seing the comic strip as media and the students can create their own imagination. Comic strip as media can enlarge their knowledge in learning english.

3. The other researcher, increase some information to get the good media to imporved reading comprehension.

\section{References}

[1] Al - Quran, QS Al - Alaq: 1-5

[2] Alice C Ommagio, language teaching in context, proficiency-oriented instruction. Boston: Heinle \& heinle, 1986

[3] Bernard, J and Lee, L 2004. select readings upper intermediate New york: oxford university press

[4] Callahan F and L.H. Clark, teaching in the middle and secondary school. Planning for competence. (USA:Mc Millian po.co.inc, 1982)

[5] David hopkins, a teacher's guide to classroom research. Open university press, England goodman and burke

[6] Grabe, W and stoller, FL 2002. teaching and researching reading. London:Longman

[7] Grabe \& stoller. 2002. Teaching and researching reading. England: pearson education

[8] Jun Liu, "effects of comic strips on L2 learners' reading comprehension", tesol quarterly, 38, 2, june, 2004, p.99

[9] Keith Rayner, barbara foorman, charles perfetti, david pesetsky, and mark sedenberg (november 2001). "how psychological science inform the teaching of reading"

[10] Kemmis, s and Taggart, the action research oanner, 3rd, Geelong: Deakin university, 1998

[11] LLC. "effectivenenss define effectiveness at dictionary.com" dictionary,com. Find the meanings and definitions of words at dictionary.com.2011 
[12] Lynne Cameron, teaching language to young learners, (cambridge: cambridge university press, t.t)

[13] Mahmud Y Yazid, the quran: an english translation of the meaning of the quran, (lebanon, Dar, al chaura , 1980)

[14] Mc Graw, reading comprehension program research base, wright group. 2001

[15] Mikulecky, B. S 2004, more reading power: reading for pleasure, comprehnsion, skill thinking skills, reading faster (2nd edition), new york: longman

[16] Richards. Jack and Rodgers, theodore's. 1986. Approaches and methods in language teaching. A description and analysis. Sydne: cambridge university press.

[17] Richard J Watts, the pragmalinguistic analysis of narrative texts: narrative cooperation. 1981: gunter narr verlag tubningen

[18] Salim razi, the effects of cultural schema and reading activities on reading comprehension: omsekiz mart, Turkey

[19] Simanjuntak, developing reading skill for english foreign language students, (Jakarta: Depdikbud, 1988)

[20] Suci Azurah, "improving the students' achievement in reading comprehension by using picture story media at $A$ sucessful start for prek-4 readers (3rd edition). Boston, pearson

[21] Wallace M,J 1998. Action research for language teacher: united kingdom: cambridge university

[22] William Grabe and fredericka L. Stoller, teaching and researching reading, (Harlow: pearson education limited, 2002)

[23] Wixson, peters, weber \& roeber, 1987, citing the new definition of reading for michigan. England: wixson press 